\title{
DESIGN OF A CONTROLLER FOR IDEAL POSITIONING SERVOSYSTEM
}

Urgency of the research. In advanced mechatronics, motion systems are the key technology, since mechanical systems such as Microelectronics manufacturing equipments are often required for high speed and accuracy. As a result, the increasing influence of the dynamics of the mechanical system on the quality of the position servosystem is noticeable. One of the important dynamic effects is the dynamics of the mechatronic system's vibroisolation, which arises as a result of the reaction force generated by the action variable.

Target setting. The aim of the paper was to design a PID controller for an ideal positioning servosystem. Ideal positioning servosystem consists of a one mass which is actuated by the Fservo force.

Actual scientific researches and issues analysis. In modern controllers, in the correction error value, classic feedback combines with forwarding feedback. The forward control is based on the fact that if the model of the mechanical actuator is known and all the initial conditions are zero, the desired position can be reached without the use of feedback.

Uninvestigated parts of general matters defining. From a theoretical point of view, it has been devoted to ideal positioning servosystem for quite a long time, but the results achieved are rarely used in practice. One of the reasons is their theoretical focus, using complex mathematics, and as a result there is a great gap between theory and engineering practice.

The research objective. Design of PID controller is based on equation for crossover frequencies, which allows to determine the derivative and integration constant of a PID controller for a given bandwidth.

The statement of basic materials. The most important dynamic effects that impact the properties of actuators are actuator flexibility, flexibility of system limited mass and rigidity of the stationary part of the system. From the equation for the eigenfrequency $\omega D P$ of the low-pass second order filter is determined. Finally, the specific gain $P$ is determined to suit the amplitude and phase margin. This completes the design of the ideal positioning servosystem.

Conclusions. PID controller for an ideal positioning servosystem is design based on equation for crossover frequencies, which allows to determine the derivative and integration constant of a PID controller for a given bandwidth.

Keywords: Motion control; vibroisolation; stability; performance control system.

Fig.: 7. References: 10.

Introduction. In [1] discusses the demands for proper tools for computer aided control system design of mechatronic systems and identifies a number of tasks in this design process. Real mechatronic design, involving input from specialists from varying disciplines, requires that the system can be represented in multiple views. The idea of feedback to make corrective actions based on the difference between the desired and the actual values of a quantity can be implemented in many different ways [3]. In modern controllers, in the correction error value, classic feedback combines with forwarding feedback. The forward control is based on the fact that if the model of the mechanical actuator is known and all the initial conditions are zero, the desired position can be reached without the use of feedback. The required feedback characteristics, which are generally expressed within the bandwidth, depend very much on the errors of the system [2 - 10]. The three most important dynamic effects that have impact on parameters of actuators are:

- actuator flexibility,

- flexibility of the system,

- limited mass and rigidity of the stationary part of the system [5].

Ideal positioning servosystem. Ideal positioning servosystem consists of a one mass which is actuate by the $\mathrm{F}_{\text {servo }}$ force. This force is generated by PID controller with which it is involved in a series of the low-pass second order filter. Position of mass $\mathrm{m}_{\mathrm{A}}$ represents the actuator and is measured to the relatively fixed base.

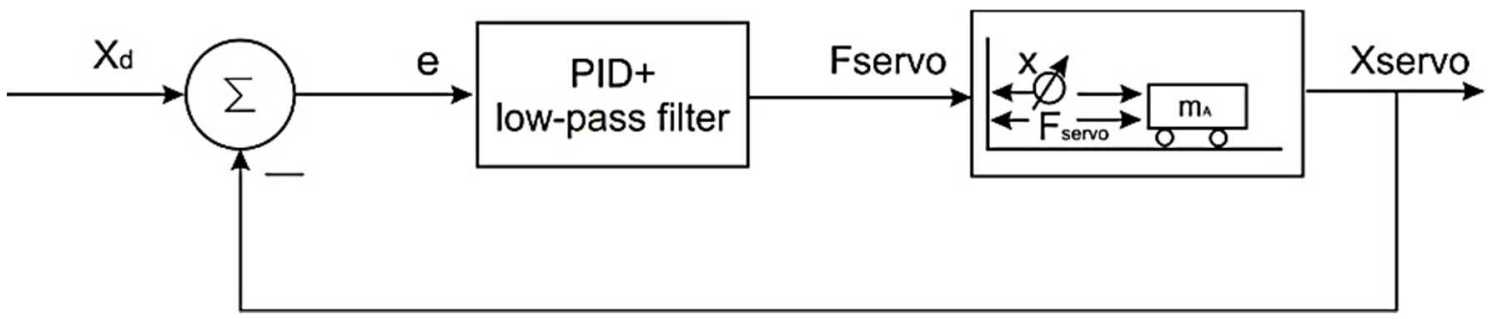

Fig. 1. Closed loop control system of ideal positioning servosystem 
TECHNICAL SCIENCES AND TECHNOLOGIES

To derive the transfer function of the PID controller and the low pass filter of the 2nd order, we start from the typical crossover frequencies for the PID controller with the low pass filter of the 2 nd order related to the bandwidth, which is defined by frequency $f_{s p}$. The following relations used for the crossover frequencies:

$$
\begin{aligned}
f_{I} & =\frac{f_{s p}}{10} \\
f_{D} & =\frac{f_{s p}}{3} \\
f_{D P} & =4 . f_{s p}
\end{aligned}
$$

The relationship between PID controller constants and crossover frequencies can be derived from the following PID controller transfer function, where $\mathrm{P}$ is proportional, D - derivative and I - integral values:

$$
R(s)=P\left(1+D s+\frac{I}{s}\right)=\frac{P\left(s+D s^{2}+I\right)}{s}=\frac{P D\left(s^{2}+\frac{1}{D}+\frac{I}{D}\right)}{s}
$$

Then:

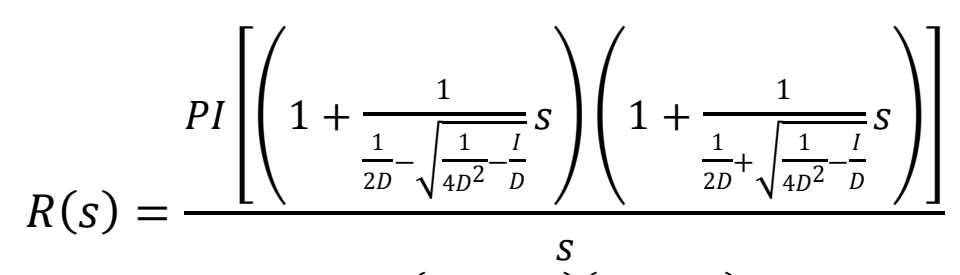

$$
\begin{aligned}
& R(s)=\frac{P I\left(1+T_{D} s\right)\left(1+T_{I} s\right)}{s} \\
& T_{D}=\frac{1}{\frac{1}{2 D}-\sqrt{\frac{1}{4 D^{2}}-\frac{I}{D}}} \\
& T_{I}=\frac{1}{\frac{1}{2 D}+\sqrt{\frac{1}{4 D^{2}}-\frac{I}{D}}}
\end{aligned}
$$

For crossover frequencies we get:

$$
\begin{gathered}
\omega_{D}=\frac{1}{T_{D}} \rightarrow f_{D}=\frac{1}{2 \pi T_{D}} \\
\omega_{I}=\frac{1}{T_{I}} \rightarrow f_{I}=\frac{1}{2 \pi T_{I}}
\end{gathered}
$$

This means that we get the integration constant $\mathrm{I}$ and the derivative constant $\mathrm{D}$ for the controller from the following set of two equations of two unknowns:

$$
\begin{aligned}
& \frac{\frac{1}{2 D}+\sqrt{\frac{1}{4 D^{2}}-\frac{I}{D}}}{2 \pi}=\frac{f_{s p}}{10} \\
& \frac{\frac{1}{2 D}-\sqrt{\frac{1}{4 D^{2}}-\frac{I}{D}}}{2 \pi}=\frac{f_{s p}}{3}
\end{aligned}
$$

The proportional constant then adjusts the gain to ensure that the position actuator is stable. The Bode characteristic in the asymptotic approximation for the PID controller (without filter) is shown in fig. 2. 


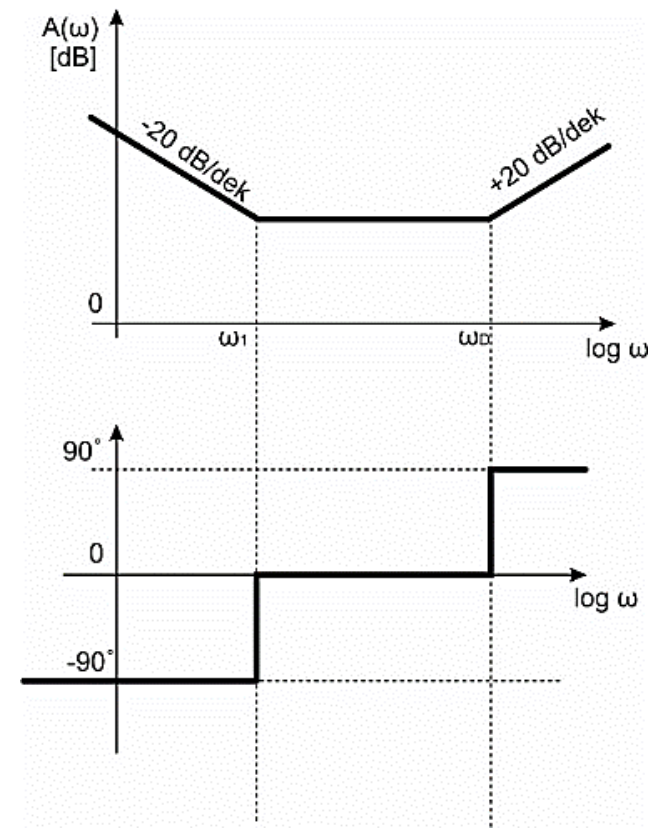

Fig. 2. Bode characteristic of PID controller

We will consider the transfer function of the low-pass second order filter in the form:

$$
G_{F(s)}=\frac{\omega_{D P}^{2}}{s+2 \xi_{F} \omega_{D P}+\omega_{D P}^{2}}
$$

In this equation, the damping factor $\xi_{F}$ and the eigenfrequency $\omega_{D P}$, which represents the break frequency, are present. This frequency must satisfy the condition in the equations for crossover frequencies.

$$
\omega_{D P}=2 \pi 4 f_{s p}
$$

We will consider a small overshoot of the low-pass second order filter, so we choose the damping factor $\xi_{F}=0,7$ The asymptotic approximation of the Bode characteristic of the lowpass second order filter is shown in fig. 3 .

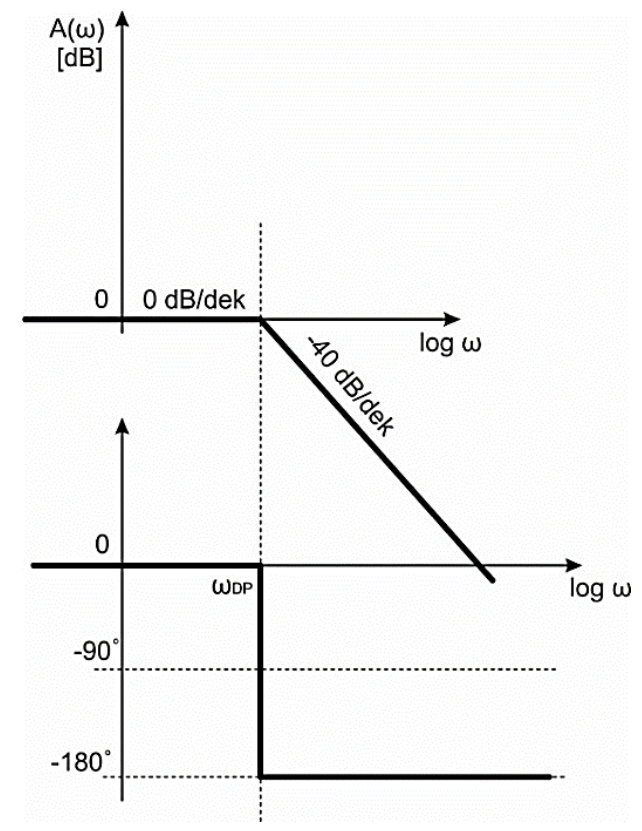

Fig. 3. The asymptotic approximation of the Bode characteristic of the low-pass second-order filter 
TECHNICAL SCIENCES AND TECHNOLOGIES

From the above-mentioned partial Bode characteristics its clear, that is possible to construct the overall characteristics of the PID controller and the second-pass low-pass second order filter. Its graphical representation in asymptotic form is shown in Fig. 4.

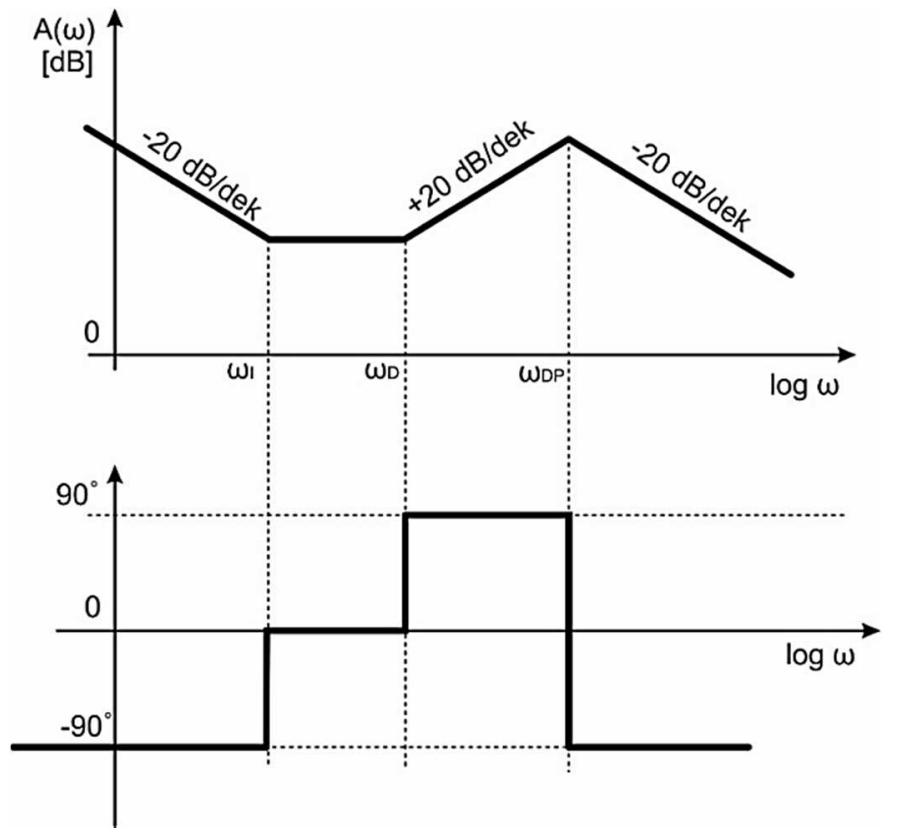

Fig. 4. Asymptotic approximation of Bode characteristic

It has already been mentioned that the actuator is represented as a mass of the $\mathrm{mA}$ applied to the force FSERVO.

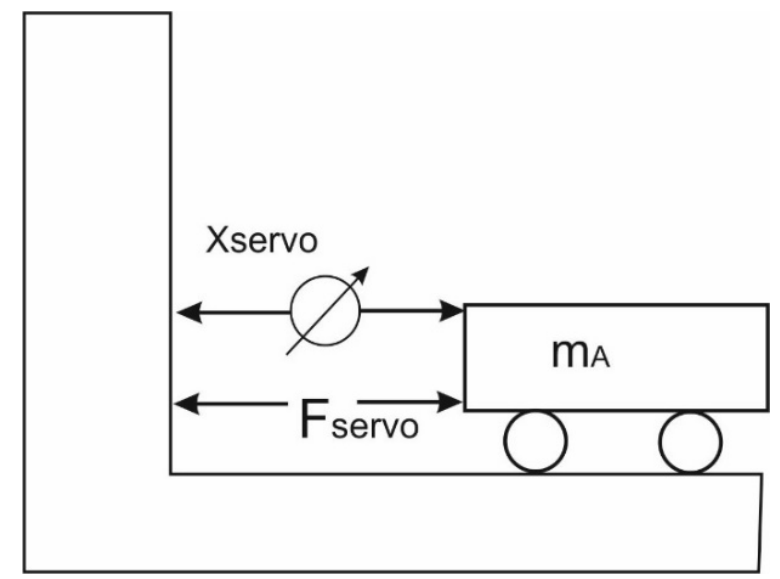

Fig. 5. Model of actuator of ideal positioning servosystem

The dependence between the output variable of the $\mathrm{X}_{\text {SERVO }}$ actuator and the input variable F SERVO is described by the equation:

$$
m_{A}=\frac{d^{2} X_{S E R V O}}{d t^{2}}=F_{S E R V O}
$$

The transfer function is then:

$$
\frac{X_{S E R V O}(s)}{F_{S E R V O}(s)}=\frac{1}{m_{A} s^{2}}
$$

The corresponding Bode characteristic is shown in fig. 6 . Throughout the whole frequency range, the amplitude characteristic has a slope $-40 \mathrm{~dB} / \mathrm{dek}$ and the phase frequency characteristic is equal $-\pi$. 

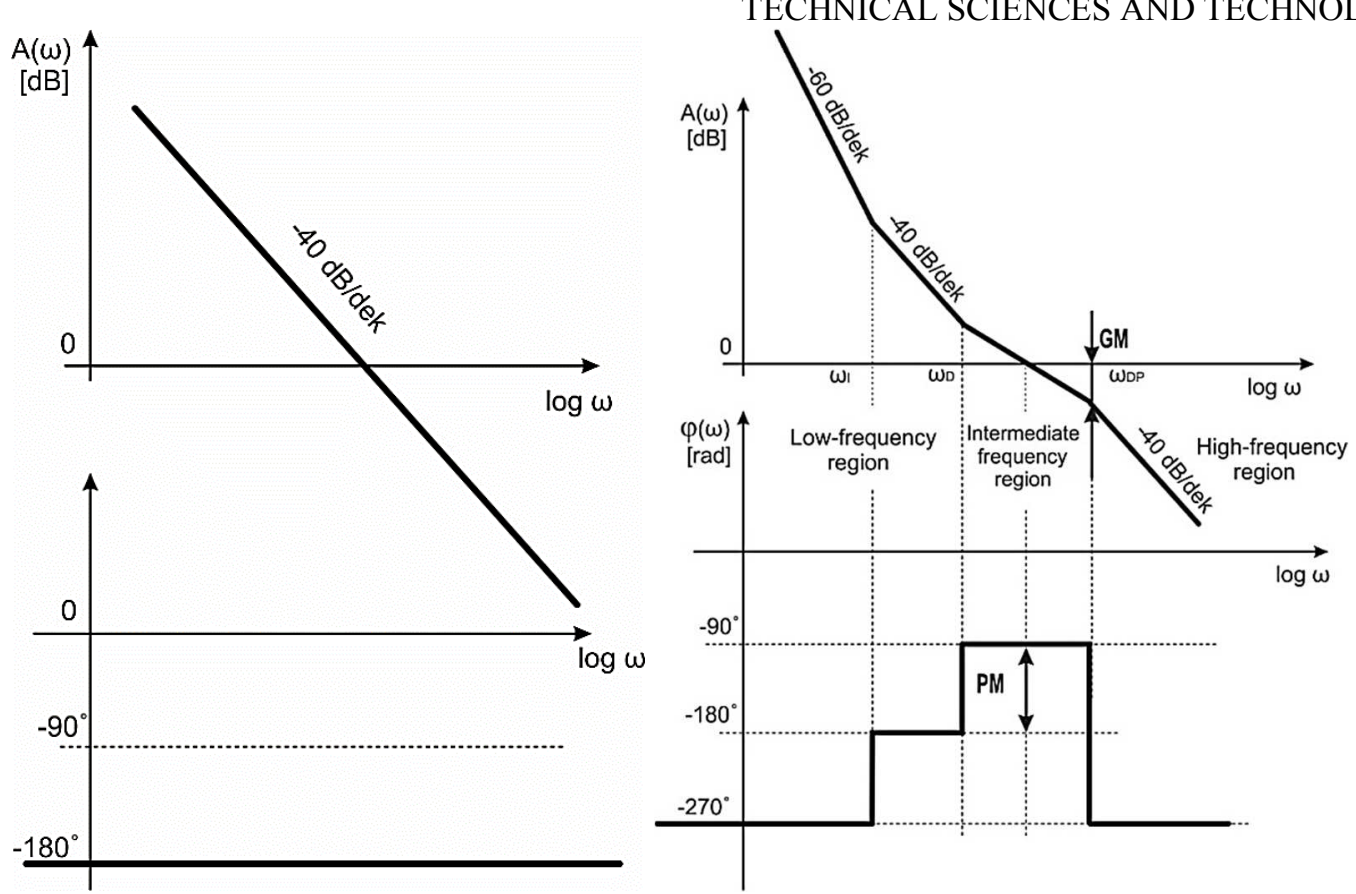

Fig. 6. Bode characteristics of the actuator of the positioning servosystem and Bode characteristic of open loop the positioning servosystem

Where PM - Phase margin and GM - Gain margin. Amplitude and phase margin determine the degree of stability and basicaly show, how close to the point $(-1.0)$ is the frequency characteristic in the complex plane. Amplitude margin determines how many times the gain $\mathrm{P}$ of the proportional term of the PID controller can be increased before the positioning servosystem reaches the stability limit. Phase margin determines how much delay the excitation signal can afford at a given frequency before the phase delay reaches $-180^{\circ}$ and the feedback system reaches the stability limit. Amplitude and phase margin can be easily read from the Bode characteristic (Fig. 6). In our case, according to the gain of the proportional term of the PID controller, three cases can appear, which are illustrated by the Nyquist characteristic in Fig. 7.
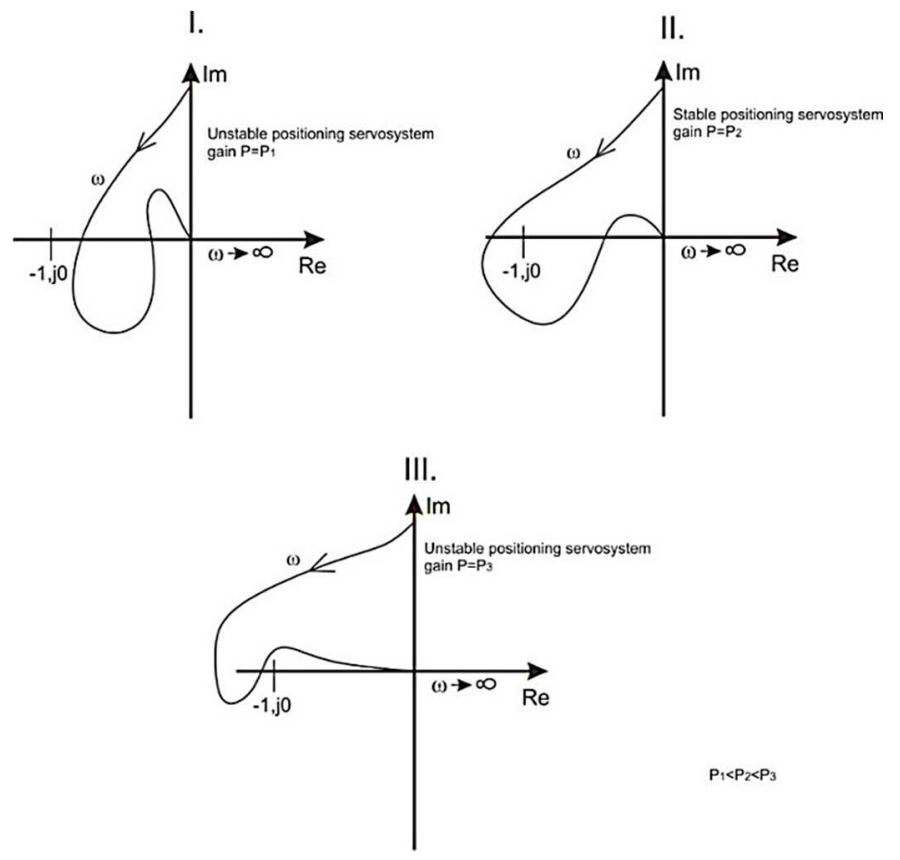

Fig. 7. Frequency characteristic of open ideal positioning servosystem for different gain of the proportional term of the PID controller 
TECHNICAL SCIENCES AND TECHNOLOGIES

From these frequency characteristics follows, that the permissible gain $\mathrm{P}$ is limited both from above and below. Therefore, a suitable gain value $\mathrm{P}$ must ensure sufficient margin in both amplitude and phase.

Conclusion. The aim of this article was to design a PID controller for an ideal positioning servosystem. Its design is based on equation for crossover frequencies, which allows to determine the derivative and integration constant of a PID controller for a given bandwidth. From the equation for the eigenfrequency $\omega_{\mathrm{DP}}$ of the low-pass second order filter is determined. Finally, the specific gain $\mathrm{P}$ is determined to suit the amplitude and phase margin. This completes the design of the ideal positioning servosystem.

Acknowledgement. This research was funded by Slovak Grant Agency VEGA1/0872/16 "Research of synthetic and biological inspired locomotion of mechatronic systems in rugged terrain" and by project Slovak Grant Agency VEGA 1/0389/18 "Research on kinematically redundant mechanisms".

\section{References}

1. Amerongen, J., Coelingh, E., De Vries, T. J. A. (2000). Computer support for mechatronic control system design, Robotics and autonomous systems, no 30.

2. Åström, K., Hägglund, T. (1995) PID Controllers: Theory, Design, and Tuning, USA: Instrument Society of America, Research Triangle Park, North Carolina.

3. Åström, K., Murray, R. M. (2008) Feedback Systems. Library of Congress Cataloging-inPublication Data, North Carolina, ISBN 978-0-691-13576-2.

4. Bishop, R. (2002). The Mechatronics Handbook. CRC Press, ISBN 0-8493-0066-5.

5. Rankers, A. M. (1997). Machine dynamics in mechatronics systems, An Engineering Approach, Philips Electronics N. V., ISBN: 90-365-0957-2.

6. Sandin, E. P. (2003). Robot mechanisms and mechanical devices, ISBN 0-07-142928-X.

7. Fatikow, S., Rembold, U. Microsystem Technology and Microrobotics. Berlin: Springer Verlag, 1997, ISBN: 3540606580.

8. Fukuda, T., Menz, W. (1998). Micro mechanical systems, principles and technology. Amsterdam: Elsevier, ISBN: 044482363.

9. Isermann, R., Münchhof, M. (2003) Identification of Dynamic Systems, Springer-Verlag London Berlin Heidelberg, ISBN 978-3-540-78878-2.

10. Janschek, K. Mechatronic systems design, Springer Heidelberg Dordrecht, London, ISBN 9783-642-17531-2.

\section{УДК 004.4}

\section{Любииа Микова}

\section{ПРОЕКТУВАННЯ КОНТРОЛЕРА ДЛЯ ІДЕАЛЬНОГО ПОЗИЦІОНУВАННЯ СЕРВОСИСТЕМ}

\footnotetext{
Актуальність теми дослідження. У сучасній мехатроніиі основними технологіями є рухові системи, оскільки такі механічні системи, як, наприклад, виробництво обладнання для мікроелектроніки. часто вимагають високої швидкості та точності позиціонування. В результаті помітний зростаючий вплив динаміки механічної системи на якість позиціонування сервосистеми. Одним із важливих динамічних ефектів є динаміка віброізоляиї мехатронної системи, яка виникає внаслідок дії реакційної сили, щя генерується змінною дї.

Постановка проблеми. Ідеальна сервосистема позиціонування складається з маси, яка приводиться в дію силою Fservo. Цю силу задає PID-контролер, ще включений послідовно з низькочастотним фільтром другого порядку.

Аналіз останніх досліджень і публікацій. У сучасних контролерах класичний зворотний зв'язок поєднується 3 прямим зворотним зв'язком за значенням помилки. Пряме управління засноване на тому факті, що якщо модель механічного приводу відома і всі початкові умови дорівнюють нулю, бажаного положення можна досягти без використання зворотного зв'язку.

Виділення недосліджених частин загальної проблеми. Теоретична точка зору довгий час була прив'язана до ідеальної сервосистеми позиціонування, але отримані результати рідко використовуються на практиці. Однією з причин є їх теоретична направленість з використанням складної математики, $i$, як результат, існує великий розрив між теорією і інженерною практикою.
}

Постановка завдання. Проектування РID-контролера засноване на рівнянні для частот зрізу, що дозволяє визначати диференційну та інтегральну складові PID-контролера для заданої пропускної здатності. 
TECHNICAL SCIENCES AND TECHNOLOGIES

Виклад основного матеріалу. Три найважливімі динамічні ефекти, що впливають на властивості приводів, - ие гнучкість приводу, гнучкість системи, обмежена маса та жорсткість нерухомої частини системи. 3 рівняння для власної частоти $\square D P$ визначається низькочастотний фільтр другого порядку. Нарешті, пропориійна складова $P$ визначається відповідно до амплітуди та фази. Це завериує проектування ідеальної сервосистеми позиціонування.

Висновки відповідно до статmі. Метою статті було розробити PID-контролер для ідеальної сервосистеми позиціонування. Його конструкція заснована на рівнянні для частот зрізу, щэо дозволяє визначати диференційну та інтегральну складові PID-контролера для заданої пропускної здатності.

Ключові слова: контроль руху; віброізолячія; стабільність; система контролю продуктивності.

Рис.: 7. Бібл: 10

Mikova Lubica - associate professor, Ph.D. of technical sciences Faculty of Mechanical Engineering, Technical University of Kosice (Letna 9, 04200 Kosice, Slovak Republic).

Любица Микова - доцент, кандидат технических наук, Технічний університет Кошице (Letna 9, 04200 Kosice, Slovak Republic).

E-mail: lubica.mikova@tuke.sk

Scopus Author ID: 55259674100 